\title{
New pyrazolo[1',5':1,6]pyrimido[4,5-d]pyridazin-4(3H)-ones as potent and selective PDE5 inhibitors
}

\author{
Joan Feixas, ${ }^{\mathrm{b}}$ Maria Paola Giovannoni, ${ }^{\mathrm{a}}$ Claudia Vergelli, ${ }^{\mathrm{a}}$ Amadeu Gavaldà, ${ }^{\mathrm{b}}$ \\ Nicoletta Cesari, ${ }^{a}$ Alessia Graziano ${ }^{\mathrm{a}}$ and Vittorio Dal Piaz ${ }^{\mathrm{a}, *}$ \\ ${ }^{a}$ Dipartimento di Scienze Farmaceutiche, Università di Firenze, Via U. Schiff 6, Sesto Fiorentino 50019, Firenze, Italy \\ ${ }^{\mathrm{b}}$ Almirall Prodesfarma Research Center, Cardener 68-74, 08024 Barcelona, Spain
}

Received 6 October 2004; revised 21 February 2005; accepted 28 February 2005

\begin{abstract}
A series of potent PDE5 inhibitors with high selectivity versus PDE6 isoenzymes was identified. (C) 2005 Elsevier Ltd. All rights reserved.
\end{abstract}

\section{Introduction}

Phosphodiesterases 5 (PDE5) are enzymes responsible for the hydrolysis of cyclic guanosine-3',5'-phosphate (cGMP) and are mainly distributed in kidney, spleen, lung and smooth muscle tissue. ${ }^{1}$ PDE5 inhibitors, elevating cGMP levels, represent very attractive agents for the treatment of cardiovascular pathologies and erectile dysfunction (ED)., ${ }^{2,3}$ This latter is a common problem in men over 40, and in the United States alone more than 30 million men suffer from ED. ${ }^{4-6}$ Penile smooth muscle relaxation is mainly mediated by nitric oxide (NO) released from vascular endothelium and parasympatic nerve ending. NO stimulates the soluble guanilate cyclase to increase cGMP levels which, acting as an intracellular second messenger, induces the relaxation of smooth muscle cells of corpus cavernosus. ${ }^{7}$ PDE5 inhibitors, stopping the process of hydrolysis of cGMP, enhance these effects and related erectile function.

The first PDE5 inhibitor used for treating male erectile dysfunction (MED) was Sildenafil (Viagra ${ }^{\mathrm{TM}}$ ) $\mathbf{1}^{8-10}$ in 1998 (see Fig. 1). This drug, despite its potency, showed many notable side effects such as nausea, headache, cutaneous flushing and retinal effects (bluish haze, or increased light sensitivity) due to inhibition of PDE6 isoform. ${ }^{11,12}$ The research in this field, aimed at discovering more selective PDE5 inhibitors, led to very

\footnotetext{
* Corresponding author. Tel.: +39 55 4573681; fax: +39 55 4573671; e-mail: vittorio.dalpiaz@unifi.it
}

potent compounds with reduced secondary effects such as Vardenafil $\mathbf{2}^{13}$ and Tadalafil $3 .^{14}$ The latter was launched (Cialis ${ }^{\mathrm{TM}}$ ) for treatment of MED at the beginning of 2003 showing a longer half-life $(>17 \mathrm{~h})$ with respect to Sildenafil and the absence of colour vision disturbances and cardiovascular effects. ${ }^{15,16}$ Very promising results are coming from Bristol-Myers research which has identified some substituted pyrazolopyridopyridazines of type 4 as potent $\left(\mathrm{IC}_{50}=0.03-0.3 \mathrm{nM}\right)$ and selective PDE5 inhibitors, orally bioavailable, potentially useful in the treatment of ED. ${ }^{17}$

Our studies in the field of PDE inhibitors ${ }^{18-21}$ led us to design and develop a new series of pyrazolopyrimidopyridazinones (compounds $\mathbf{1 0}-\mathbf{4 2}$ ), structurally related to compound 4, showing a good inhibitory activity on PDE5 and a fair selectivity towards PDE6.

\section{Chemistry}

Compounds 10 $\mathbf{4 2}$ were prepared by following the general procedure reported in Scheme 1. Isoxazolo[3,4- $d$ pyridazin-7 $(6 H)$-one 6 was obtained by treatment with hydrazine of isoxazole $\mathbf{5}$, following the synthetic procedure reported in the literature. ${ }^{22}$ Intermediate 6 was condensed with the opportune arylaldehydes (or pivalic aldehyde) to give the vinyl derivatives $7 .^{23}$ Treatment of compounds 7 with hydrazine in ethanol afforded, in very good yields, the pyrazole intermediates 8 by opening the isoxazole ring and at the same time closure to pyrazole. ${ }^{24}$ Compounds 9 were obtained by treatment of 4 amino-5-(1H-pyrazol-5-yl)pyridazin-3(2H)-ones 8 with 

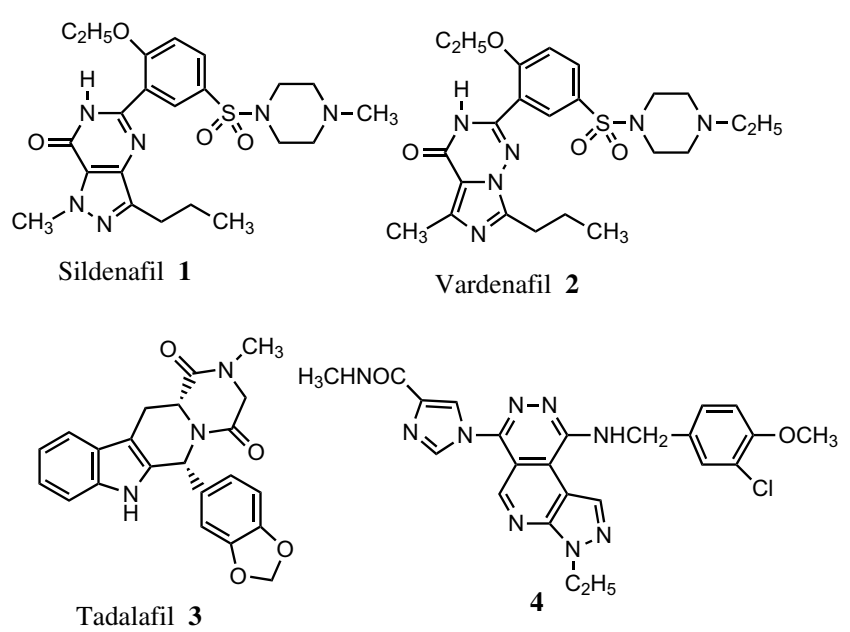

Figure 1.

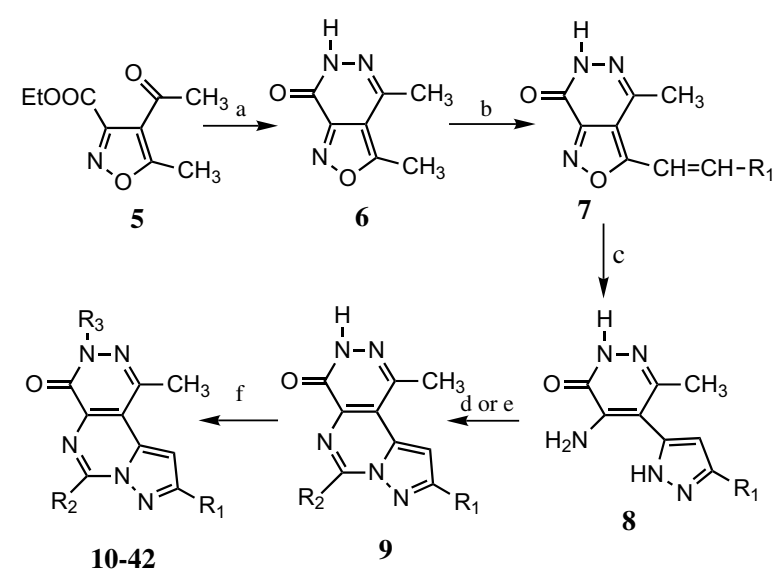

Scheme 1. Reagents and conditions: (a) hydrazine hydrate, EtOH, rt; (b) $\mathrm{R}_{1} \mathrm{CHO}, \mathrm{MeONa}$, abs $\mathrm{MeOH}$, reflux; (c) hydrazine hydrate, $\mathrm{EtOH}$, rt; (d) $\left(\mathrm{R}_{2} \mathrm{CO}\right)_{2} \mathrm{O}$, reflux; (e) $\mathrm{R}_{2} \mathrm{COOH}$, dichloromethane, anhydrous DMF, DMAP, EDC, reflux; (f) $\mathrm{R}_{3} \mathrm{X}, \mathrm{NaH}$, DMSO, rt.

the opportune anhydride under refluxing conditions without solvent. When acids were used, the condensation was performed at room temperature using 1-[3-(dimethylamino)propyl]-3-ethylcarbodiimide hydrochloride as coupling agent and the resulting amides were then thermally cyclized. Finally, alkylation of the pyrazolopyrimidopyridazinones $\mathbf{9}$ with a variety of halides in standard conditions afforded the final compounds 10-42.

\section{Results and discussion}

All compounds were evaluated for their ability to inhibit PDE5 and PDE6. PDE5 was purified from human platelets as described by Gristwood et al. ${ }^{25}$ PDE6 was purified from bovine retinas as described by Beavo et al. $^{26}$ Cyclic nucleotide phosphodiesterase activities were measured using a two-step procedure according to Thompson and Strada. ${ }^{27}$ Sildenafil was used as reference drug.
The first term of this series was compound $\mathbf{1 0}\left(\mathrm{R}_{1}=\mathrm{Ph}\right.$, $\mathrm{R}_{2}=\mathrm{Me}, \mathrm{R}_{3}=\mathrm{Bn}$ ), for which an appreciable activity and selectivity was found $\left(\mathrm{IC}_{50}=160 \mathrm{nM}\right.$ for PDE5 and $25 \%$ inhibition at $2 \mu \mathrm{M}$ for PDE6). Keeping the same tricyclic skeleton, structural modifications were performed at $\mathrm{R}_{1}, \mathrm{R}_{2}$ and $\mathrm{R}_{3}$ and related results are summarized in Table 1 .

As regards substituents $R_{1}$ at position 9 of the tricyclic system, aryl, substituted phenyl as well as $t$-butyl groups were inserted. Data showed a good activity associated with the presence of a 2-pyridyl ring (compounds 18, $\mathrm{IC}_{50}=270 \mathrm{nM}$ ) comparable to $\mathbf{1 0}$. Introduction of an amino group in para position of the phenyl (compound 20) reduced the activity $\left(\mathrm{IC}_{50}=920 \mathrm{nM}\right)$, but increased the selectivity towards PDE6 isoenzymes $(4.5 \%$ inhibition at $2 \mu \mathrm{M}$ ) with respect to the more active compounds 10 and 18. On the other hand, a complete loss of potency was found for the 3,4-methylenedioxy and the 4nitrophenyl derivatives $\mathbf{1 6}$ and $\mathbf{1 9}$, indicating that steric and electronic factors may limit the tolerance in this position. Finally, also the $t$-butyl derivative resulted completely inactive, suggesting that the aromatic system in this part of the molecule could play a significant role in determining PDE5 inhibitory activity.

Modifications of substituent $R_{2}$ at position 6 gave interesting results, achieving for some compounds $\mathrm{IC}_{50} \mathrm{~s}$ in the 34-81 $\mathrm{nM}$ range. Starting from the analysis of aromatic and aralkyl substituents, it seems that exact requirements were necessary. In fact, when a pyridyl system was inserted at 6 , different results were obtained depending on the linked position. The 2-pyridyl derivative (compound 24) is the most interesting compound, showing a very good balance of potency and selectivity versus PDE5 $\left(\mathrm{IC}_{50}=81 \mathrm{nM}\right.$ for PDE5 and $21.3 \%$ at $2 \mu \mathrm{M}$ for PDE6). The potency, together with the selectivity, decreased when a 3-pyridyl ring was inserted (compound 25), but a complete loss of activity was observed for the 4-pyridyl derivative (26), suggesting that the nitrogen could be involved in a specific bond. On the other hand, activity and selectivity were restored by inserting a methylenic spacer (compound 22). The 6-phenyl derivative 21 showed an analogous potency $\left(\mathrm{IC}_{50}=81 \mathrm{nM}\right)$ to compound $\mathbf{2 4}$, but lower selectivity. Introduction of an alkyl spacer between the phenyl ring and the tricyclic system led to different results: the benzyl derivative $\mathbf{2 3}$ was found completely devoid of activity, whereas the insertion of a phenylethyl residue partially restored the inhibitory activity (compound $27, \mathrm{IC}_{50}=980 \mathrm{nM}$ ). A good level of potency and selectivity was found for compound 29, in which a $m$-tolyl was inserted; on the contrary, the isomer $o$-tolyl led to an inactive product indicating that steric factors could play an important role for interaction with the biological target. Similarly, compounds 30 and 31, in which a cyclohexylmethyl and a cyclopentylmethyl residue respectively were inserted, are completely inactive. Very interesting results were obtained by the introduction of alkyl chains and functionalized alkyl chains. For this type of substituent a higher tolerance seems to be allowed since the $\mathrm{IC}_{50} \mathrm{~s}$ of all tested compounds are in the $430-434 \mathrm{nM}$ range. 
Table 1. PDE5 and PDE6 inhibitory activity of compounds $\mathbf{1 0 - 4 2}$<smiles>[R]c1cc2c3c(C)nn([R])c(=O)c3nc([R])n2n1</smiles>

10-42

\begin{tabular}{|c|c|c|c|c|c|}
\hline Compd & $\mathrm{R}_{1}$ & $\mathrm{R}_{2}$ & $\mathrm{R}_{3}$ & PDE5 $\mathrm{IC}_{50}$ or $\%$ inhibition $(\mu \mathrm{M})^{\mathrm{b}}$ & PDE6 $\mathrm{IC}_{50}$ or $\%$ inhibition $(\mu \mathrm{M})^{\mathrm{b}}$ \\
\hline 10 & $\mathrm{Ph}$ & $\mathrm{Me}$ & $\mathrm{Bn}$ & 0.16 & $25(2)$ \\
\hline 11 & $\mathrm{Ph}$ & $\mathrm{Me}$ & Cyclohexylmethyl & 3.1 & 11 \\
\hline 12 & $\mathrm{Ph}$ & $\mathrm{Me}$ & $p$-Nitrobenzyl & $65.9(20)$ & $10.4(2)$ \\
\hline 13 & $\mathrm{Ph}$ & $\mathrm{Me}$ & p-Aminobenzyl & 1.1 & 2.0 \\
\hline 14 & $\mathrm{Ph}$ & $\mathrm{Me}$ & $\mathrm{Ph}$ & $11.9(0.2)$ & $3.7(0.2)$ \\
\hline 15 & $\mathrm{Ph}$ & $\mathrm{Me}$ & $m$ - $\left(\mathrm{H}_{2} \mathrm{PO}_{4}\right)$ benzyl & 0.23 & $28.6(0.2)$ \\
\hline 16 & $\mathrm{~A}^{\mathrm{a}}$ & $\mathrm{Me}$ & $\mathrm{Bn}$ & 13.0 & 78 \\
\hline 17 & $t$-Butyl & $\mathrm{Me}$ & $\mathrm{Bn}$ & $31.0(2)$ & $-20.9(2)$ \\
\hline 18 & 2-Pyridyl & $\mathrm{Me}$ & $\mathrm{Bn}$ & 0.27 & 10 \\
\hline 19 & 4-Nitrophenyl & $\mathrm{Me}$ & $\mathrm{Bn}$ & $65.5(20)$ & $14.4(0.2)$ \\
\hline 20 & 4-Aminophenyl & $\mathrm{Me}$ & $\mathrm{Bn}$ & 0.92 & $4.5(2)$ \\
\hline 21 & $\mathrm{Ph}$ & $\mathrm{Ph}$ & $\mathrm{Bn}$ & 0.081 & 2.8 \\
\hline 22 & $\mathrm{Ph}$ & 4-Pyridylmethyl & $\mathrm{Bn}$ & 0.45 & $20.4(2)$ \\
\hline 23 & $\mathrm{Ph}$ & $\mathrm{Bn}$ & $\mathrm{Bn}$ & $22.5(2)$ & $13.6(2)$ \\
\hline 24 & $\mathrm{Ph}$ & 2-Pyridyl & $\mathrm{Bn}$ & 0.081 & $21.3(2)$ \\
\hline 25 & $\mathrm{Ph}$ & 3-Pyridyl & $\mathrm{Bn}$ & 0.18 & $17.7(2)$ \\
\hline 26 & $\mathrm{Ph}$ & 4-Pyridyl & $\mathrm{Bn}$ & $69.0(2)$ & $-4.8(2)$ \\
\hline 27 & $\mathrm{Ph}$ & Phenylethyl & $\mathrm{Bn}$ & 0.98 & 30 \\
\hline 28 & $\mathrm{Ph}$ & $o$-Tolyl & $\mathrm{Bn}$ & $55.1(2)$ & $-16.6(2)$ \\
\hline 29 & $\mathrm{Ph}$ & $m$-Tolyl & $\mathrm{Bn}$ & 0.075 & $11.5(2)$ \\
\hline 30 & $\mathrm{Ph}$ & Cyclohexylmethyl & $\mathrm{Bn}$ & $33.6(2)$ & $19.2(2)$ \\
\hline 31 & $\mathrm{Ph}$ & Cyclopentylmethyl & $\mathrm{Bn}$ & $18.2(2)$ & $4.2(2)$ \\
\hline 32 & $\mathrm{Ph}$ & $\mathrm{CH}_{2} \mathrm{OCH}_{3}$ & $\mathrm{Bn}$ & 0.1 & $53.3(2)$ \\
\hline 33 & $\mathrm{Ph}$ & $\mathrm{CH}_{2} \mathrm{OCH}_{2} \mathrm{CH}_{3}$ & $\mathrm{Bn}$ & 0.35 & $45(2)$ \\
\hline 34 & $\mathrm{Ph}$ & $\mathrm{CH}_{2} \mathrm{SCH}_{3}$ & $\mathrm{Bn}$ & 0.1 & $38.1(2)$ \\
\hline 35 & $\mathrm{Ph}$ & $\mathrm{CH}_{2} \mathrm{CH}_{2} \mathrm{COOH}$ & $\mathrm{Bn}$ & 0.43 & 0.59 \\
\hline 36 & $\mathrm{Ph}$ & $\mathrm{CH}=\mathrm{CHCOOH}$ & $\mathrm{Bn}$ & 0.32 & 0.58 \\
\hline 37 & $\mathrm{Ph}$ & $\left(\mathrm{CH}_{2}\right)_{3} \mathrm{COOH}$ & $\mathrm{Bn}$ & 0.03 & 0.11 \\
\hline 38 & $\mathrm{Ph}$ & $\left(\mathrm{CH}_{2}\right)_{4} \mathrm{COOH}$ & $\mathrm{Bn}$ & 0.09 & 0.063 \\
\hline 39 & $\mathrm{Ph}$ & $\mathrm{CH}\left(\mathrm{C}_{2} \mathrm{H}_{5}\right)_{2}$ & $\mathrm{Bn}$ & 0.067 & $37.4(2)$ \\
\hline 40 & $\mathrm{Ph}$ & $\mathrm{CH}\left(\mathrm{CH}_{3}\right) \mathrm{CH}_{2} \mathrm{CH}_{3}$ & $\mathrm{Bn}$ & 0.034 & $42.5(2)$ \\
\hline 41 & $\mathrm{Ph}$ & $\mathrm{CH}\left(\mathrm{CH}_{3}\right) \mathrm{CH}_{2} \mathrm{CH}_{3}$ & $m$ - $\left(\mathrm{H}_{2} \mathrm{PO}_{4}\right)$ benzyl & 0.059 & $66.9(2)$ \\
\hline 42 & 2-Pyridyl & $\mathrm{CH}\left(\mathrm{CH}_{3}\right) \mathrm{CH}_{2} \mathrm{CH}_{3}$ & $\mathrm{Bn}$ & 0.039 & $34.6(2)$ \\
\hline Sildenafil & & & & 0.020 & 0.040 \\
\hline
\end{tabular}

${ }^{\mathrm{a}} \mathrm{A}=3,4$-methylendioxyphenyl.

${ }^{\mathrm{b}} \mathrm{The} \mathrm{IC}_{50}$ were obtained from dose-response curves at three or four different concentrations $(n=2-3)$.

Ether derivatives (32 and 33) and the corresponding thioether 34, as well as the carboxylic acids $\mathbf{3 5}$ and 36, showed a good level of activity and an appreciable selectivity with the exception of compounds $\mathbf{3 5}$ and $\mathbf{3 6}$ which demonstrated the same affinity for PDE5 and PDE6 isoenzymes. Homologation of carboxylic acid 35 (compounds 37 and 38) resulted in an increase of potency, but, as the above compounds, in the complete absence of selectivity $\left(\mathrm{IC}_{50}=30,90 \mathrm{nM}\right.$ for PDE5 and $\mathrm{IC}_{50}=110,63 \mathrm{nM}$ for PDE6). The best results were associated with the introduction of branched chains (compounds 39 and 40) which showed a significant improvement of the potency with respect to the corresponding 6-methyl derivative 10. These compounds appeared particularly interesting because of their high activity towards PDE5 associated to very good selecti- vity $\left(\mathrm{IC}_{50}=67\right.$ and $34 \mathrm{nM}$ for PDE5; 37.4\% and $42.5 \%$ inhibition at $2 \mu \mathrm{M}$ for PDE6).

Finally, some modifications were performed at position 3 by inserting substituents on the benzyl group as well as by removing the methylenic spacer with the introduction of a phenyl ring. The best result is related to the introduction of a phosphate group at meta position of the benzyl (compound 15), the activity being comparable, but not improved with respect to the 3-unsubstituted benzyl derivative $\mathbf{1 0}$.

The best substituents selected for position 9,6 and 3 (2pyridyl, $\mathrm{CH}\left(\mathrm{CH}_{3}\right) \mathrm{CH}_{2} \mathrm{CH}_{3}$ and $m$ - $\left(\mathrm{H}_{2} \mathrm{PO}_{4}\right)$-benzyl, respectively) were finally combined in compounds $\mathbf{4 1}$ and $\mathbf{4 2}$ in order to verify if hybridization is allowed. In 
both cases activity and selectivity are very good, but no improvement of potency was found, suggesting that the combining approach is not effective.

\section{Conclusion}

In conclusion we have identified a novel series of potent and selective PDE5 inhibitors potentially useful as peripheral vasodilators. The most interesting compounds showed values of PDE5 inhibitory activity in the same nanomolar range of Sildenafil but with a much better selectivity versus PDE6; this last aspect could make them good candidates to be used as MED treating drugs devoid of some well-known unwanted effects.

Further modifications at positions 9, 6, 3 and 1 are in progress to completely define structure-activity relationships and in order to improve the potency and selectivity profile of the present series.

\section{Acknowledgements}

Support of this work by MURST (40\%, Italy) is gratefully acknowledged.

\section{References and notes}

1. Juilfs, D. M.; Soderling, S.; Burns, F.; Beavo, J. A. Rev. Physiol., Biochem. Pharmacol. 1999, 135, 67-104.

2. Czarniecki, M.; Ahn, H. S.; Sybertz, E. J. Annu. Rep. Med. Chem. 1996, 31, 61-70.

3. Truss, M. C.; Stief, C. G. Drugs Today 1998, 34, 805-812.

4. Corbin, J. D.; Francis, S. H. J. Biol. Chem. 1999, 274 , 13729-13732.

5. Melman, A.; Gingell, J. C. J. Urology 1999, 161, 5-11.

6. Ayta, I. A.; McKinlay, J. B.; Krane, R. J. Brit. J. Urol. BJU 1999, 84, 50-56.

7. Andersson, K. E.; Wagner, G. Physiol. Rev. 1995, 75, 191236.
8. Terrett, N. K.; Bell, A. S.; Brown, D.; Ellis, P. Bioorg. Med. Chem. Lett. 1996, 6, 1819-1824.

9. Brook, G. Drugs Today 2000, 36, 125-134.

10. Sorbera, L. A.; Martin, L.; Leeson, P. A.; Castaner, J. Drugs Future 2001, 26, 15-19.

11. Beavo, J. A. Physiol. Rev. 1995, 75, 725-748.

12. Scrip 1997 (October 9).

13. Vardenafil Drugs Future 2001, 26, 141.

14. Eardley, I.; Cartledge, J. Int. J. Clin. Pract. 2002, 56, 300304.

15. Gresser, U.; Gleiter, C. H. Eur. J. Med. Res. 2002, 7, 435446.

16. Porst, H. Int. J. Impot. Res. 2002 (Suppl 1), S57S64.

17. Yu, G.; Mason, H.; Wu, X.; Wang, J.; Chong, S.; Beyer, B.; Henwood, A.; Pongrac, R.; Seliger, L.; He, B.; Normandin, D.; Ferref, P.; Zhang, R.; Adam, L. M.; Humprey, W. G.; Krupinski, J.; Macor, J. E. J. Med. Chem. 2003, 46, 457-460.

18. Dal Piaz, V.; Giovannoni, M. P.; Castellana, M. C.; Palacios, J. M.; Beleta, J.; Domènech, T.; Segarra, V. J. Med. Chem. 1997, 40, 1417-1421.

19. Dal Piaz, V.; Giovannoni, M. P.; Castellana, M. C.; Palacios, J. M.; Beleta, J.; Domènech, T.; Segarra, V. Eur. J. Med. Chem. 1998, 33, 789-797.

20. Dal Piaz, V.; Giovannoni, M. P. Eur. J. Med. Chem. 2000, $35,463-480$.

21. Dal Piaz, V.; Castellana, M. C.; Vergelli, C.; Giovannoni, M. P.; Gavaldà, A.; Segarra, V.; Beleta, J.; Ryder, H.; Palacios, J. M. J. Enzym. Inhib. Med. Chem. 2002, 17, 227-233.

22. Renzi, G.; Dal Piaz, V. Gazz. Chim. Ital. 1965, 95, 14781491.

23. Dal Piaz, V.; Pinzauti, S.; Lacrimini, P. J. Heterocycl. Chem. 1976, 13, 409-410.

24. Dal Piaz, V.; Ciciani, G.; Chimichi, S. Heterocycles 1986, 24, 3143-3148.

25. Gristwood, R. W.; Beleta, J.; Bou, J.; Cardelus, I.; Fernandez, A. G.; Llenas, J.; Berga, P. Br. J. Pharmacol. 1992, 105, 985-991.

26. Beavo, J. A.; Conti, M.; Haeslip, R. J. Mol. Pharmacol. 1984, 46, 399-405.

27. Thompson, W. J.; Strada, S. J. In Methods of Enzymatic Analysis; Bergmayer, H. U., Ed.; John Wiley \& Sons: Germany, 1984; Vol. IV, pp 127-134. 